\title{
Overview and Evaluation of Existing Guidelines for Rational Antimicrobial Use in Small-Animal Veterinary Practice in Europe
}

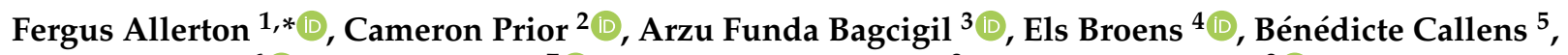 \\ Peter Damborg ${ }^{6}{ }^{\oplus}$, Jeroen Dewulf ${ }^{7}{ }^{\infty}$, Maria-Eleni Filippitzi ${ }^{8}$, Luís Pedro Carmo ${ }^{9}{ }^{\circledR}$, Jonathan Gómez-Raja ${ }^{10}{ }^{\circledR}$, \\ Erez Harpaz ${ }^{11}$, Ana Mateus ${ }^{12}$, Mirja Nolff ${ }^{13} \oplus$, Clare J. Phythian ${ }^{11} \oplus$, Dorina Timofte ${ }^{14} \oplus$, Flavia Zendri ${ }^{14}$ \\ and Lisbeth Rem Jessen ${ }^{15}$
}

check for

updates

Citation: Allerton, F.; Prior, C.; Bagcigil, A.F.; Broens, E.; Callens, B.; Damborg, P.; Dewulf, J.; Filippitzi, M.-E.; Carmo, L.P.; Gómez-Raja, J.; et al. Overview and Evaluation of Existing Guidelines for Rational Antimicrobial Use in Small-Animal Veterinary Practice in Europe. Antibiotics 2021, 10, 409. https:// doi.org/10.3390/antibiotics10040409

Academic Editor: Albert Figueras

Received: 15 March 2021

Accepted: 6 April 2021

Published: 9 April 2021

Publisher's Note: MDPI stays neutral with regard to jurisdictional claims in published maps and institutional affiliations.

Copyright: (c) 2021 by the authors. Licensee MDPI, Basel, Switzerland. This article is an open access article distributed under the terms and conditions of the Creative Commons Attribution (CC BY) license (https:// creativecommons.org/licenses/by/ $4.0 /)$.
1 Willows Veterinary Centre and Referral Service, Highlands Road, Shirley, Solihull B90 4NH, UK

2 Veterinary Specialists Scotland, 1 Deer Park Road Livingston, Scotland EH54 8AG, UK; Cameron.Prior@vetscotland.co.uk

3 Department of Microbiology, Faculty of Veterinary Medicine, Istanbul University-Cerrahpaşa, 34320 Avcilar, Istanbul, Turkey; fucigil@iuc.edu.tr

4 Faculty of Veterinary Medicine, Department of Biomolecular Health Sciences, Utrecht University, Yalelaan 1, 3584 CL Utrecht, The Netherlands; E.M.Broens@uu.nl

5 Centre of Knowledge on Antimicrobial Use and Resistance, Galileelaan 5/02, 1210 Brussels, Belgium; benedicte.callens@amcra.be

6 Department of Veterinary and Animal Sciences, University of Copenhagen, Stigbøjlen 4, 1870 Frederiksberg, Denmark; pedam@sund.ku.dk

7 Veterinary Epidemiology Unit, Faculty of Veterinary Medicine, Ghent University, Salisburylaan 133, 9820 Merelbeke, Belgium; jeroen.dewulf@ugent.be

8 Veterinary Epidemiology Unit, Sciensano, 1050 Brussels, Belgium; Maria-Eleni.Filippitzi@sciensano.be

9 Veterinary Public Health Institute, Vetsuisse Faculty, University of Bern, Schwarzenburgstrasse 161, 3097 Liebefeld, Bern, Switzerland; luis.gomesdocarmo@vetsuisse.unibe.ch

10 FundeSalud, Government of Extremadura, Pio Baroja 10, 06800 Mérida, Spain; Jonathan.gomez@fundesalud.es

11 Faculty of Veterinary Medicine, Institute for Production Animal Clinical Science, Norwegian University of Life Sciences, Small Ruminant Research and Herd Health, Høyland, 4325 Sandnes, Norway; erez.harpaz@nmbu.no (E.H.); clare.phythian@nmbu.no (C.J.P.)

12 Hawkshead Campus, Royal Veterinary College, University of London, Hawkshead Lane, Hatfield AL9 7TA, Hertfordshire, UK; amateus@rvc.ac.uk

13 Clinic for Small Animal Surgery Tierspital Zürich, Vetsuisse Faculty, University of Zürich, Winterthurerstrasse 260,8057 Zürich, Switzerland; mirjachristine.nolff@uzh.ch

14 Department of Veterinary Anatomy, Leahurst Campus, Institute of Infection, Veterinary and Ecological Sciences, Physiology and Pathology, University of Liverpool, Neston CH64 7TE, UK;

D.Timofte@liverpool.ac.uk (D.T.); Flavia.Zendri@liverpool.ac.uk (F.Z.)

15 Department of Veterinary Clinical Sciences, Faculty of Health Sciences, University of Copenhagen, Dyrlægevej 16, 1870 Frederiksberg C, Denmark; lrmj@sund.ku.dk

* Correspondence: fergus.allerton@willows.uk.net

Abstract: Antimicrobial stewardship guidelines (ASGs) represent an important tool to help veterinarians optimize their antimicrobial use with the objective of decreasing antimicrobial resistance. The aim of this study was to map and qualitatively assess the ASGs for antimicrobial use in cats and dogs in Europe. Country representatives of the European Network for Optimization of Veterinary Antimicrobial Treatment (ENOVAT) were asked to identify ASGs published in their countries. All collated ASGs updated since January 2010 containing recommendations on antimicrobial therapy for at least three conditions affecting different organ systems in cats and dogs underwent detailed review including AGREE II analysis. Out of forty countries investigated, fifteen ASGs from eleven countries met the inclusion criteria. Several critical principles of antimicrobial use were identified, providing a framework that should assist development of stewardship guidance. The AGREE II analysis highlighted several methodological limitations of the currently available ASGs. This study sheds light on the lack of national ASGs for dogs and cats in multiple European countries and should encourage national bodies to prioritize guideline development in small animals. A greater awareness of the need to use a structured approach to guideline development could improve the quality of ASGs in the future. 
Keywords: antimicrobial stewardship; antimicrobial resistance; guidelines; AGREE II; canine; feline

\section{Introduction}

In response to the rising threat to both human and animal health from multidrugresistant (MDR) infections [1,2], there is an urgent need to adopt measures to preserve the efficacy of available antimicrobials. Since antimicrobial use (AMU) is recognized as a key driver of antimicrobial resistance (AMR) [3], any steps that can reduce unnecessary or inappropriate AMU should diminish the selection pressure for resistant bacterial strains. The vast majority of AMU in animals occurs on farms promoting development of AMR and creating an important potential reservoir of resistance genes [4]. A 35\% decrease in aggregated overall sales (in mg/population correction unit) was documented in Europe from 2011 to 2018, reflecting stewardship efforts in agriculture [5]. In companion animals, the overall AMU is substantially lower compared to production animals and the sales of antimicrobial tablets (a surrogate measure of AMU in companion animals) accounted for $1.1 \%$ of the total sales in tons in 2018 although the proportion was higher $(5.2-10.3 \%)$ in some countries [5].

However, the use of critically important antimicrobials belonging to the European Medicines Agency (EMA) AVOID USE and/or RESTRICT USE categories may be more common in companion animals compared to production animals [6]. For example, in a food-producing country such as Denmark, companion animals account for the majority of veterinary fluoroquinolone consumption despite representing only $1 \%$ of the total veterinary AMU. Ignoring companion animals in the One Health equation on AMR may prove to be unwise as multidrug-resistant bacteria including methicillin-resistant Staphylococcus aureus (MRSA) [7,8], vancomycin-resistant enterococci (VRE) [9,10], extendedspectrum beta-lactamase (ESBL), AmpC and carbapenemase-producing Gram-negative bacteria $[9,11-13]$ have been isolated in dogs and cats. This represents an important potential reservoir of resistance genes; transmission to susceptible bacteria could pose a serious risk to human health.

Encouraging rational AMU is a fundamental principle of antimicrobial stewardship programs (ASPs). In veterinary practice, a range of approaches have been adopted across Europe including the imposition of regulations restricting the use of specific antimicrobials and the promotion of voluntary antimicrobial stewardship guidelines (ASGs) at the national and clinical levels [14-21]. Restrictive policies limiting the use of particular antimicrobials in food-producing animals are already in place in several European countries and will come into force across the European Union in January 2022 [22]. In contrast, antimicrobial stewardship in companion animals in Europe relies more heavily on AMU guidelines, with few legislative measures which are mainly limited to Northern European countries.

To the authors' knowledge, the only previous review of the main veterinary prudent use guidelines was performed in 2012 and included only those published in English [23]. The availability and quality of ASGs for dogs and cats in Europe have not been recently investigated.

The European Network for Optimization of Veterinary Antimicrobial Treatment (ENOVAT) is a European Cooperation in Science and Technology (COST) Action-a network dedicated to scientific collaboration with special emphasis on the development of ASGs and refinement of microbiological diagnostic procedures. A primary objective of the ENOVAT is to map and compare the availability, structure, and evidence base of veterinary ASG in Europe. This study focuses on national guidelines in Europe pertaining to cats and dogs only. By characterizing common features of published antimicrobial guidelines, it may be possible to build a framework of key recommendations that can inform other national organizations that are in the process of developing their own strategies. The Appraisal of Guidelines for Research and Evaluation Instrument (AGREE II) [24] was developed to address the issue of variability in the quality of best practice guidelines and has previously 
been applied to surgical prophylaxis guidelines in veterinary medicine [25]. The AGREE II instrument was incorporated into this study to offer an objective assessment of the identified guidelines, and to highlight aspects of the guideline preparation process that may be of relevance to future developers.

\section{Materials and Methods}

\subsection{Identification of Potential Guideline Documents}

Representatives of every country participating in the ENOVAT COST Action were contacted by email to inform them of this study and to seek assistance in the identification of ASGs offering recommendations pertaining to cats and dogs. Country representatives were asked to identify ASGs for cats and dogs published in their countries. In addition, they were invited to perform an internet search to find published ASGs, with searches to be performed in English and all official languages of the respective country. Search terms were 'antimicrobial' or 'antibiotic' or 'antibacterial'; and 'stewardship' or 'guidelines' and 'cat' or 'dog' or 'companion animal' or 'veterinary'. A further search verification step involved country representatives contacting their respective, national veterinary organizations (particularly those engaged in companion animal work) to assist in providing this information. Details of all identified ASGs were collated; the absence of appropriate guidelines after completion of the searches was also recorded. A centralized database of ASGs (the global repository of available guidelines for responsible use of antimicrobials in animal health) hosted by the World Veterinary Association [26] was also checked.

All ASGs, published or updated since January 2010, in any of the countries represented in the ENOVAT were eligible. If more than one version of any guideline was available in this timeframe, only the latest update was evaluated. To be included in the descriptive analysis, the guideline had to provide recommendations on the empirical use of antimicrobial therapy for at least three conditions affecting different organ systems in cats and dogs. A recommendation, per the World Health Organization Handbook for guideline development, implies a choice between different interventions (e.g., the decision to use antimicrobials) that have an impact on patient health and wider implications for the use of resources [27].

\subsection{Evaluation of Identified Antimicrobial Stewardship Guidelines}

Eligible guidelines were reviewed, either in their original language or after translation into English via an online translation tool (Google Translate) by two of the authors and responses were compared. All discordant results were verified and discussed to ensure a consensus was reached. Qualitative descriptors of each guideline document were recorded including the format of the document (book, poster, digital application/tool or document); the type of group responsible for the production of the guidelines (government body, national organization, society, university or an interested group); accessibility online; paid or free access to guidelines; what other species were included in the guidelines; and the languages in which the documents were available.

Specific features of each guideline document were reviewed including the number of organ systems for which recommendations were available; whether general principles of responsible AMU were included; whether common bacterial pathogens were listed for each infection; whether the use of appropriate diagnostic techniques for aseptic sample collection and for the identification of putative organisms (e.g., bacterial culture or cytology) were promoted and whether a mechanism for providing feedback to the guideline authors was incorporated.

The guidelines were also evaluated to see whether they contained advice not to administer antimicrobials in particular conditions including acute diarrhea, feline lower urinary tract disease (FLUTD), subclinical bacteriuria or peri/post-operatively for certain classifications of surgical procedure (clean $+/$ - clean contaminated surgical wound class). The guidelines were assessed to see whether they included recommendations to preferentially select narrow rather than broad-spectrum antimicrobials; suggested doses and durations of antimicrobial therapy; contained warnings about potential adverse effects associated 
with certain antimicrobials; and incorporated recommendations to monitor AMU and local resistance patterns. The specification of particular antimicrobials that should not be used in animals and of antimicrobials classified as highest priority critically important antibiotics (HPCIAs), the inclusion of advice on management of multidrug-resistant (MDR) bacterial infections and consideration of zoonotic risk from particular pathogens were also evaluated.

The AGREE II instrument [24] was used to critically evaluate six domains, covering the scope and purpose of the guidelines, stakeholder involvement, rigor of development, clarity of presentation, applicability and editorial independence, and an overall guideline assessment. Each element was rated on a 7-point Likert-like scale from strongly disagree (1) to strongly agree (7). Individual domain scores were calculated by summing individual item scores in each domain and scaling the total as a percentage of the maximum possible score for that domain. The scaled domain score was calculated as Equation (1):

$$
\text { Domain score }=100 \times \frac{\text { Obtained score }- \text { Minimum possible score }}{\text { Maximum possible score }- \text { Minimum possible score }}
$$

Self-directed training material available on the AGREE Trust website (https: / www. agreetrust.org/resource-centre/agree-ii/agree-ii-training-tools/, accessed on 1 March 2021) was completed by each appraiser. Each guideline was appraised using the AGREE II instrument by four veterinarians from a panel of nine vets with an interest in antimicrobial stewardship and proficiency in English and at least one of the other languages of the selected guidelines. Appraisal data were collated and median domain scores calculated for each guideline. Domain results were evaluated separately and no pre-defined quality thresholds were set. Interrater reliability was assessed by calculation of intraclass correlation coefficient (ICC) using a one-way random-effects model and average measures. SPSS Statistics Software version 26.0 was used to calculate ICC per item and 95\% confidence intervals. An ICC from 0.40 to 0.59 was considered fair correlation, 0.60 to 0.74 was considered good correlation and 0.75 to 1.0 was considered excellent correlation [28].

\section{Results}

Representatives of 40 countries were contacted to provide information about antimicrobial guidelines developed or used in their respective countries (Figure 1). Replies were obtained relating to $38 / 40$ countries, identifying 23 potential guidelines from 17 different countries, a further pan-European document produced by the Federation of European Companion Animal Veterinary Associations (FECAVA) and the Guidance for the rational use of antimicrobials (GRAM) book. Ten guidelines did not meet the study inclusion criteria either because the documents were produced for owners rather than vets $(n=1)$, addressed dogs only $(n=1)$, presented lists of conditions for which antimicrobials could be used rather than proposing antimicrobials for specific conditions $(n=3)$ or provided general stewardship advice only without including specific antimicrobial recommendations for clinical conditions $(n=5)$. Fifteen ASGs were identified for detailed review (Figure 1 and Table 1).

The eligible ASGs were available in different formats-six were online documents (41-221 pages in length), five were books (ranging from 56 to 560 pages in length), two were posters and two were online tools. The two resources developed in Switzerland may be considered as complementary tools and were produced by the same collaboration. They have been evaluated separately here as, individually, they met the inclusion criteria for this study. A range of different groups have been involved in development of ASGs including representatives from Universities, governing bodies, veterinary societies, a veterinary pharmaceutical firm and independent organizations. Direct involvement of a government agency was not recorded for any of the 15 ASGs. Eight of the 15 ASGs provide recommendations for cats and dogs only. Recommendations pertaining to a broad range of other species, including ruminants (cattle, sheep or goats), pigs, horses, fish, poultry, bees, 
rabbits, rats, guinea pigs, hamsters, tortoises, lizards, crocodiles, snakes, parrots and fur animals were also included in the other seven resources.

The primary language of the ASGs reflected the official language(s) of the relevant countries in which they were developed. Six of the fifteen ASGs were available in English (Table 1). The Danish guidelines have also been translated into Chinese, Polish and Slovene; the UK guidelines into Spanish, the GRAM book into French and Spanish and the FECAVA guidelines are available in Croatian, English, French, German, Lithuanian, Polish, Portuguese and Slovene. Fourteen of the 15 ASGs could be accessed online (one of which required payment to view and download, one required registration and creation of a user account) and $8 / 15$ can also be requested as printed/hard copies (one printed book only available on payment).

A mechanism to provide feedback, in the form of a contact e-mail address, was included in 9/15 ASGs. Ten of the 15 guidelines reported that feedback on previous editions had been incorporated in the latest version. Since 2017, 11 of 15 ASGs have been updated, and new versions of three were in preparation. An accessible reference list is provided alongside $12 / 15$ of the ASGs.

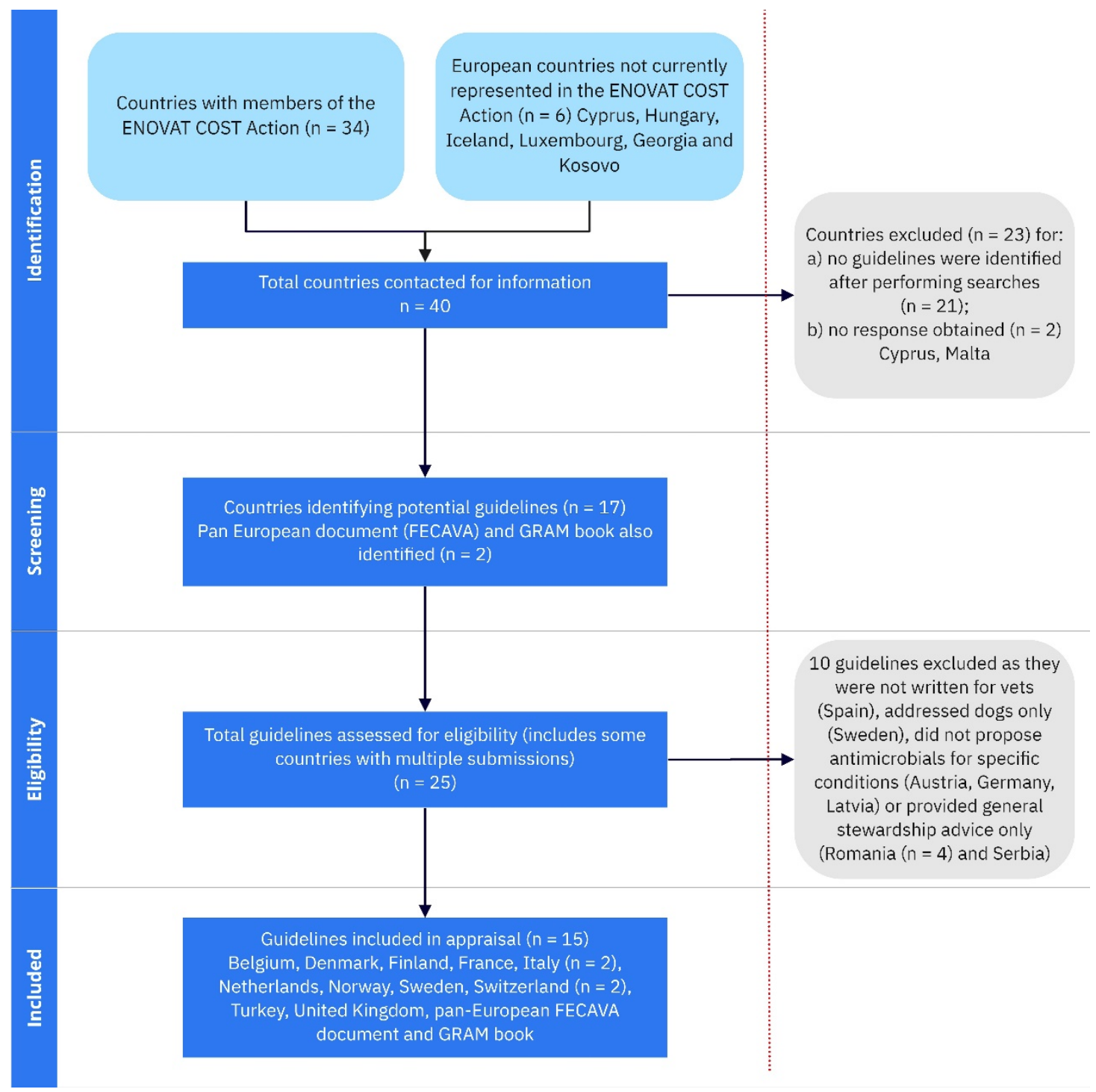

Figure 1. Flow diagram showing the identification, screening and selection of ASGs for detailed review. Excluded ASG are listed in Supplementary Table S1. 
Table 1. ASGs included in this study.

\begin{tabular}{|c|c|c|}
\hline Country & Last Updated & Antimicrobial Stewardship Guidelines (ASGs) \\
\hline Belgium & 2020 [29] & Formularium Antimicrobial Consumption and Resistance in Animals (AMCRA) \\
\hline Denmark & 2018 [30] & Antibiotic Use Guidelines for Companion Animal Practice (2nd Edition) * \\
\hline Finland & 2018 [31] & Mikrobilääkkeiden käyttösuositukset eläinten tärkeimpiin tulehdus- ja tartuntatauteihin * \\
\hline France & 2017 [32] & $\begin{array}{c}\text { Guide De Bonnes Pratiques Filière Animaux De Compagnie Fiches De Recommandations } \\
\text { Pour Un Bon Usage Des Antibiotiques } 2017\end{array}$ \\
\hline Ittaly & $2017[33]$ & Linee guida. Uso prudente dell'antibiotico negli animali da compagnia \\
\hline Italy & $2017[34]$ & Linee Guida sul corretto uso degli antibioticinella clinica del cane e del gatto \\
\hline Netherlands & $2017[35]$ & Formularium gezelschapsdieren hond, kat en konijn \\
\hline Norway & $2014[36]$ & Terapianbefaling: Bruk av antibakterielle midler til hund og katt \\
\hline Sweden & 2010 [37] & Guidelines for the clinical use of antibiotics in the treatment of dogs and cats * \\
\hline Switzerland & $2019[38]$ & Therapieleitfaden für Tierärztinnen und Tierärzte-Hunde und Katzen \\
\hline Turkey & $2017[40]$ & Veteriner Hekimlikte Antibiyotikler (Pratik Bilgiler Rehberi) 2nd Edition \\
\hline United Kingdom & 2018 [41] & PROTECT ME poster * \\
\hline FECAVA & 2018 [42] & FECAVA Recommendations for Appropriate Antimicrobial Therapy * \\
\hline GRAM book & $2016[43]$ & Guidance for the rational use of antimicrobials * \\
\hline
\end{tabular}

Those marked with an asterisk $\left(^{*}\right)$ are also available in English.

The ASG provided recommendations for antimicrobial selection for a varied number of conditions. These were separated into a median of 9.5 different organ systems (range 413). All of the ASGs included advice to restrict the prescription of antimicrobial medication where either non-bacterial disease or bacterial infections that may self-resolve without antimicrobial therapy is suspected. Recommendations not to prescribe antimicrobials for at least one specific indication were found in all of the ASGs (Table 2).

Table 2. Frequency of recommendations in ASGs.

\begin{tabular}{|c|c|c|}
\hline Recommendation & $\begin{array}{c}\text { Number of } \\
\text { ASGs }(n=15)\end{array}$ & $\begin{array}{c}\text { Percentage of ASGs } \\
(\%)\end{array}$ \\
\hline \multicolumn{3}{|l|}{ Antimicrobials are not indicated for management of: } \\
\hline Acute diarrhea & 15 & 100 \\
\hline Clean/elective surgical procedures & 13 & 87 \\
\hline Feline lower urinary tract disease & 11 & 73 \\
\hline subclinical bacteriuria & 8 & 53 \\
\hline Non-antimicrobial therapeutic options described & 14 & 93 \\
\hline Use topical medication instead of systemic medication where appropriate & 15 & 100 \\
\hline Select narrow over broad-spectrum antimicrobials or encourage de-escalation to a narrower spectrum & 13 & 87 \\
\hline Avoid certain antimicrobials reserved for human use only, e.g., vancomycin or carbapenems & 12 & 80 \\
\hline Mention highest priority critically important antimicrobials (HPCIAs) & 10 & 66 \\
\hline Tier antimicrobial suggestions (first line, second line) & 13 & 87 \\
\hline Promote use of diagnostic techniques (cytology/culture) to identify putative bacteria & 15 & 100 \\
\hline List common pathogens found in specific conditions & 14 & 93 \\
\hline Monitor local antimicrobial resistance patterns & 5 & 33 \\
\hline Audit/monitor individual/practice AMU & 8 & 53 \\
\hline
\end{tabular}

Specificities relating to AMU such as suggested doses, treatment durations and potential adverse effects were included in 11, 14 and 11 ASGs, respectively. A recommended treatment duration for uncomplicated urinary tract infections (UTI) was described in 13/15 ASGs including 3-5 days $(n=4), 7$ days $(n=5)$ and $7-14$ days $(n=4)$. The four ASG recommending treatment durations of 3-5 days had been updated in 2018 or later. Considerations for the management of MDR bacteria (e.g., MRSA and methicillin-resistant Staphylococcus pseudintermedius (MRSP), ESBL-producing Enterobacterales) were apparent in 10 of 15 ASGs. Nine of 15 ASGs contained recommendations to observe special precautions when dealing with potential zoonotic pathogenic bacteria. 


\section{AGREE II Analysis}

Median scores for the four appraisers for each AGREE II item and all 15 ASGs are shown in Figure 2.

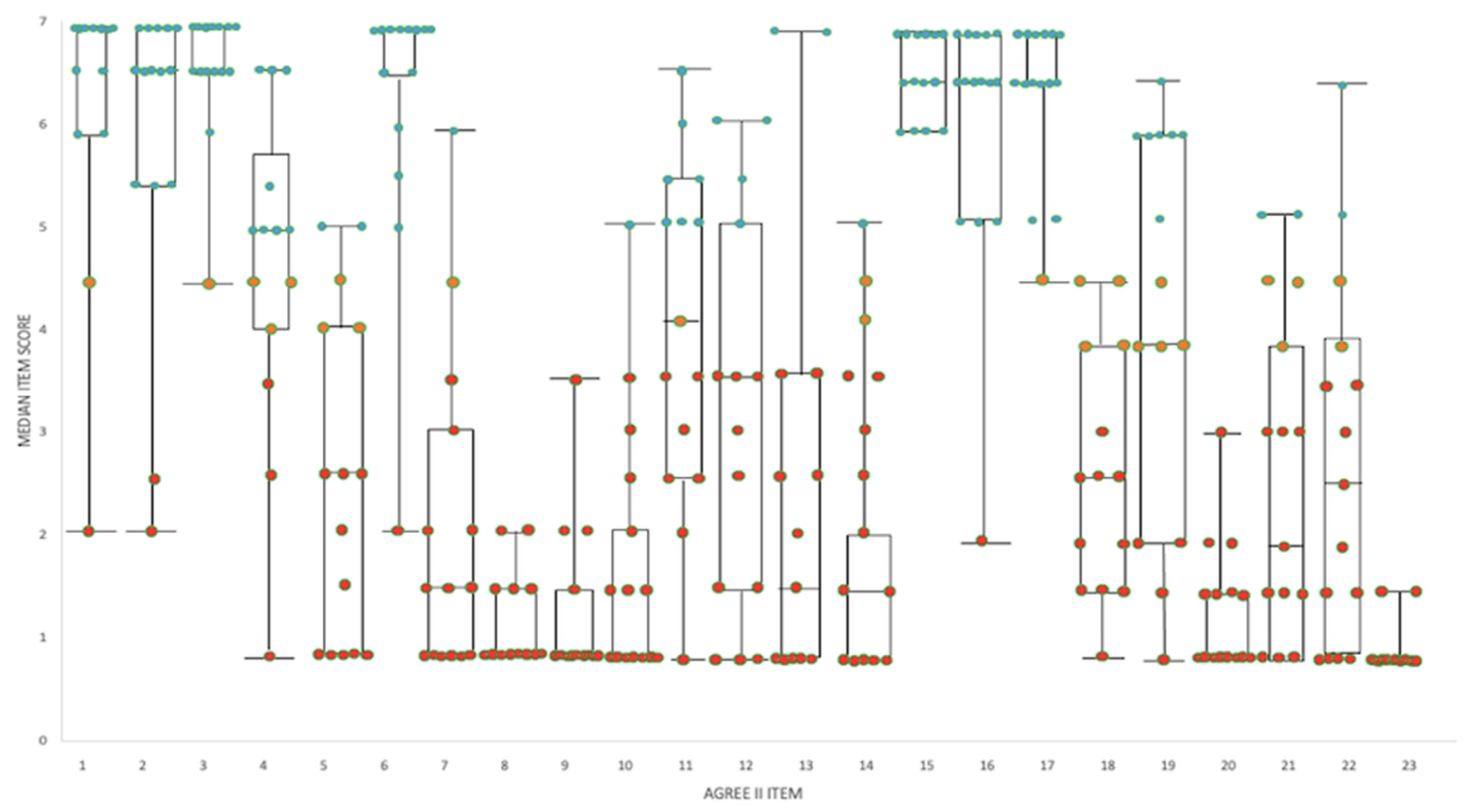

Figure 2. Box and whisker plot showing the median item score for all ASGs combined and range overlain with the median item scores for each individual ASG. Each ASG item score is represented by a color (green for median scores $\geq 5$; orange for 4-5 and red for $<4$ ). See Table 3 for the description of each AGREE II item.

Table 3. Intraclass correlation coefficients, $95 \%$ confidence intervals and interpretation for each AGREE II item.

\begin{tabular}{|c|c|c|c|c|c|}
\hline & \multirow{2}{*}{$\begin{array}{c}\text { ICC } \\
0.64\end{array}$} & \multicolumn{2}{|c|}{$\begin{array}{l}\text { 95\% Confidence } \\
\text { Interval }\end{array}$} & \multirow{2}{*}{$\frac{\text { Correlation }}{\text { Good }}$} \\
\hline 1 & The overall objective(s) of the guideline is (are) specifically described & & 0.21 & 0.86 & \\
\hline 2 & The clinical question(s) covered by the guideline is (are) specifically described & 0.28 & -0.57 & 0.73 & Poor \\
\hline 3 & The patients to whom the guideline is meant to apply are specifically described & 0.52 & -0.04 & 0.82 & Fair \\
\hline 4 & The guideline development group includes individuals from all the relevant professional groups & 0.71 & 0.36 & 0.89 & Good \\
\hline 5 & The patients' views and preferences have been sought & 0.16 & -0.82 & 0.68 & Poor \\
\hline 6 & The target users of the guideline are clearly defined & 0.57 & 0.06 & 0.84 & Fair \\
\hline 7 & Systematic methods were used to search for evidence & 0.42 & 0.26 & 0.78 & Fair \\
\hline 8 & The criteria for selecting the evidence are clearly described & -0.25 & -1.9 & 0.54 & Poor \\
\hline 9 & The strengths and limitations of the body of evidence are clearly described & 0.41 & -0.28 & 0.78 & Fair \\
\hline 10 & The methods for formulating the recommendations are clearly described & 0.56 & 0.03 & 0.83 & Fair \\
\hline 11 & The health benefits, side effects, and risks have been considered in formulating the recommendations & 0.31 & -0.49 & 0.74 & Poor \\
\hline 12 & There is an explicit link between the recommendations and the supporting evidence & 0.58 & 0.08 & 0.84 & Fair \\
\hline 13 & The guideline has been externally reviewed by experts prior to its publication & 0.70 & 0.34 & 0.89 & Good \\
\hline 14 & A procedure for updating the guideline is provided & 0.42 & -0.24 & 0.72 & Fair \\
\hline 15 & The recommendations are specific and unambiguous & 0.52 & -0.4 & 0.84 & Fair \\
\hline 16 & The different options for management of the condition are clearly presented & 0.54 & -0.01 & 0.83 & Fair \\
\hline 17 & Key recommendations are easily identifiable & 0.15 & -0.85 & 0.68 & Poor \\
\hline 18 & The guideline is supported with tools for application & 0.39 & -0.42 & 0.78 & Poor \\
\hline 19 & The potential organizational barriers in applying the recommendations have been discussed & 0.42 & -0.25 & 0.78 & Fair \\
\hline 20 & The potential cost implications of applying the recommendations have been considered & 0.02 & -1.14 & 0.63 & Poor \\
\hline 21 & The guideline presents key review criteria for monitoring and/or audit purposes & 0.12 & -0.91 & 0.67 & Poor \\
\hline 22 & The guideline is editorially independent from the funding body & 0.42 & -0.37 & 0.79 & Fair \\
\hline 23 & Conflicts of interest of guideline development members have been recorded & 0.58 & 0.01 & 0.85 & Fair \\
\hline
\end{tabular}

Median domain scores are shown in Figure 3. Overall intraclass correlation coefficient amongst reviewers in this study was excellent $(\mathrm{ICC}=0.80)$. Interrater reliability was 
individually calculated for each item rating and shown in Table 3 with scores ranging from poor correlation ( -0.25 and 0.02$)$ for items 8 and 20 to good correlation ( 0.71 and 0.70$)$ for items 4 and 13, respectively.

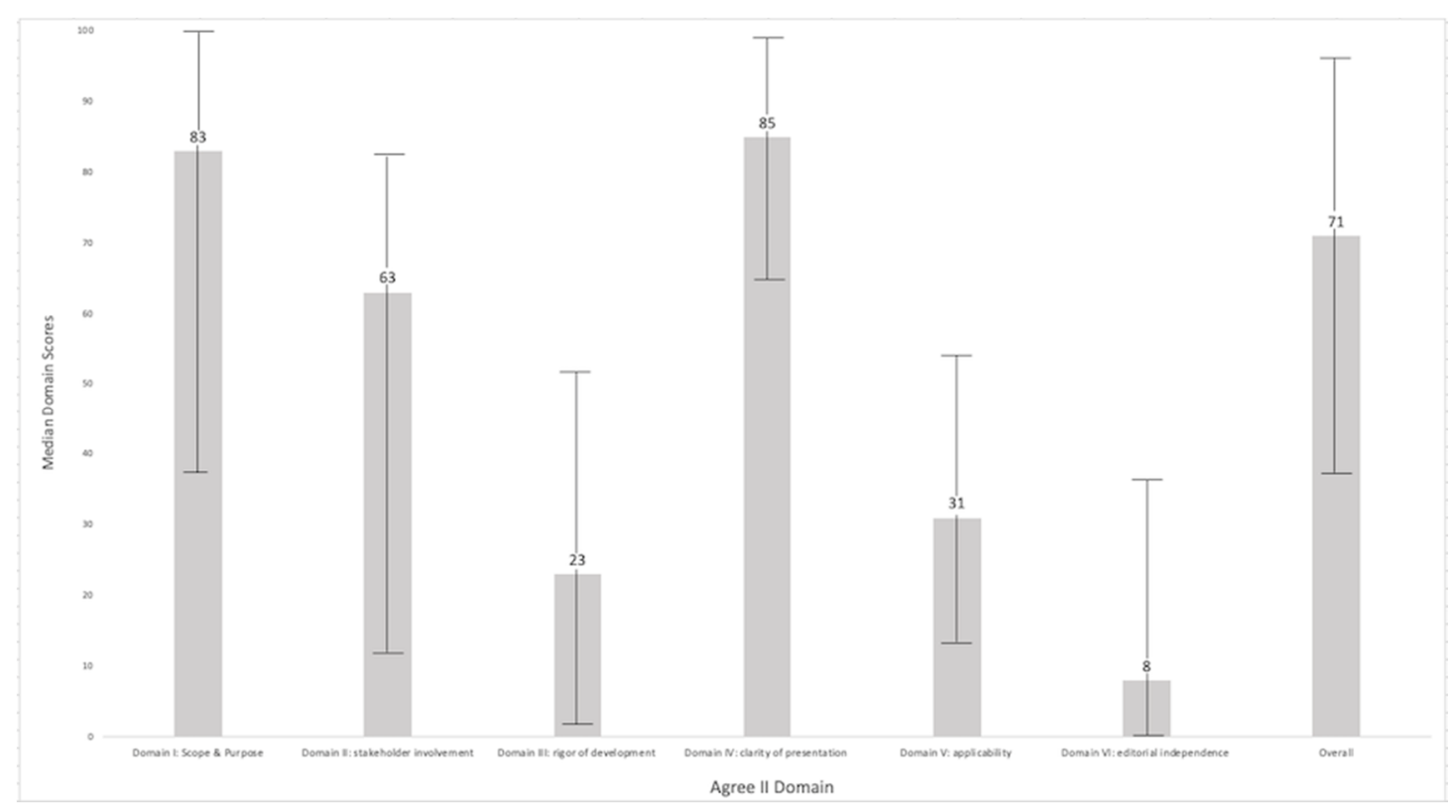

Figure 3. Median domain scores and range for all appraised ASGs.

\section{Discussion}

This study identified 15 antimicrobial stewardship guidelines on rational antimicrobial use for cats and dogs from 11 of the 40 countries investigated, highlighting a substantial gap in national recommendations for small-animal antimicrobial stewardship across Europe. None of the included guidelines were initiated by governmental initiatives, further emphasizing that small animals constitute a blind spot in the national AMU political agenda.

Antimicrobial use guidance produced in six other countries did not meet the inclusion criteria of this study (including one document produced for dogs only), several guidelines have been translated into multiple languages and 13/15 of the appraised ASGs are freely available online transcending national borders. ASGs from outside Europe have not been considered in this study; absent specific-country representatives, it was not possible to assuredly locate all ASGs in these territories. Topic-specific guidance has been disseminated by the International Society for Companion Animal Infectious Diseases (ISCAID) in the form of consensus statements [44-47], affording broader accessibility to stewardship advice. Guidelines produced by the FECAVA and the GRAM book were included in this analysis given their availability across Europe. However, national guidelines confer advantages as they can take into account local disease prevalence, AMR occurrence, AMU trends, any national regulations relating to antimicrobial prescription and the availability of antimicrobial formulations and diagnostics.

Key recommendations featured consistently across the majority of appraised ASGs, indicating adherence to a responsible AMU agenda within Europe, despite national differences. Eliminating inappropriate AMU for common, and typically benign and self-limiting, indications seems a logical and achievable target; the appearance of variants of the 'do not use' recommendations in all of the ASGs emphasizes the importance of this approach. The majority $(14 / 15)$ of ASGs also outlined appropriate non-antimicrobial therapies-a means to avoid veterinarian frustration and to provide suitable alternative therapies that may address prescription pressure from the owner [48-50].

All of the ASGs encourage pathogen identification via cytology and/or bacterial culture to guide treatment decisions. Although bacterial culture with antimicrobial suscep- 
tibility testing (AST) is considered an essential stewardship tool [51,52], studies suggest infrequent application in small-animal practice in Europe often due to cost constraints [53-55]. This disappointing dichotomy amply demonstrates the difficulty of converting a key message into implemented actions. AST facilitates optimal drug selection and de-escalation of unnecessarily broad-spectrum empiric antimicrobial therapy. The growing availability of molecular testing modalities (e.g., PCR) and matrix-assisted laser desorption/ionizationtime of flight mass spectrometry (MALDI-TOF MS) will provide veterinarians with greater opportunity to rapidly identify putative pathogens [56] and may have the potential to change diagnostic patterns.

The preferential use of narrow-spectrum antimicrobials was another commonly $(13 / 15)$ included recommendation among the ASGs. Despite recognition of the greater potential to contribute to AMR, the use of broad-spectrum formulations, such as amoxicillinclavulanate, far outweighs narrow-spectrum alternatives in Europe [57,58]. Here, external factors (e.g., drug familiarity, practice purchasing policy) are likely stronger influences in drug selection than guideline recommendations.

In a similar vein, all ASGs promoted topical rather than systemic AMU where appropriate. Given that skin conditions are among the most common motives for consultation in small-animal practice $[59,60]$, a transition to topical use could significantly decrease total AMU limiting exposure of the gut microbiota to antimicrobials and reducing AMR. Interestingly, sequential studies in the UK (performed by different animal health surveillance networks) documented a drop in systemic antimicrobial therapy from $92 \%$ to $25 \%$ in dogs with skin disease $[59,61]$. The four-year gap between the data collection for these studies coincides with the launch of the first edition of national stewardship guidelines in the UK. Greater practitioner awareness of AMR may have contributed to these improved figures.

The inclusion of an explicit statement to reserve certain antimicrobials (carbapenems, linezolid and vancomycin) exclusively for human use in 12/15 of the ASGs serves as a vital reminder to practitioners who may not appreciate the public health importance of these agents. In many countries veterinary prescribers retain the autonomy to use these antimicrobials even though this raises serious ethical questions [62,63]. In Sweden, laws prohibit all veterinary use of these antimicrobials; similar restrictions may be introduced more widely. The World Health Organization (WHO) [64] and the European Medicines Agency [65] have independently categorized some antimicrobials as HPCIAs including fluoroquinolones, macrolides and third- and above generation cephalosporins. Imminent European legislation will recommend conditioning their prescription based on AST results [22]. To encourage vets to position HPCIAs appropriately in their treatment plan, many ASGs list them as highest-tier (last resort) options, stress the requirement for AST or use different color schemes (e.g., traffic lights) to underscore their restricted application.

Antimicrobial prescription (in terms of dose and duration of therapy) should adhere to the datasheet or Summary of Product Characteristics. There are instances when deviation from standard dosing is warranted based on patient factors or pharmacokinetic considerations (e.g., target organ penetration); highlighting these situations can ensure the efficacy of antimicrobial treatment. Shorter treatment courses decrease AMU and the risk of propagating AMR; regarding antimicrobial therapy duration, a shorter is better mantra has been endorsed in human medicine $[66,67]$. This approach has spilled over into veterinary medicine; the updated 2019 ISCAID guidelines on urinary tract disease [47] favor a shorter 3-5 day course for uncomplicated UTI compared to 7-14 days in the 2011 version [68]. The 3-5 day treatment recommendation has already been adopted by four of the most recently updated ASG reviewed in this study illustrating the value of regular revision of ASGs. There is a need for clinical trials to support this approach and move forward agendas which should feed into future guideline recommendations. Ominously, practitioners in human medicine often prescribe longer courses than the duration recommended in national guidelines [69]; additional measures may be required to support vets to adopt shorter antimicrobial courses, potentially including individualized treatment lengths linked to clinical resolution or surrogate markers such as C-reactive protein [70]. 
A lack of supportive clinical data represents an important limitation inherent to most recommendations included in small-animal ASGs. Recommendations are oft derived from expert opinion and extrapolation from human medicine principles. A similar situation was recognized in the early part of this century by $\mathrm{WHO}$ [71] prompting the adoption of rigorous and transparent processes that utilize the best available evidence $[27,72]$. Tools to assist guideline development have been incorporated into the process including the Grading of Recommendations Assessment, Development and Evaluation (GRADE) approach [73,74] and the AGREE Collaboration [75]. The AGREE II instrument [24] can also be used to critically appraise existing clinical practice guidelines and was employed in this study to review the identified guidelines.

Guideline evaluation was performed by appraisers with little prior experience of AGREE II. Raters completed the training modules provided on the AGREE Enterprise website but unfamiliarity with this tool is a limitation of this study. It is recommended that at least two, and preferably four, appraisers review each clinical guideline to increase reliability. However, nine ASGs were available in six different non-English languages. A wider pool of appraisers including at least one native speaker per ASG was sought to limit miscoding. Overall inter-rater reliability (IRR) was excellent, suggesting that less than $20 \%$ of the variability in the item scores was due to random variation. IRR for individual items was lower reflecting the smaller sample sizes but 15/23 items were classified as fair or good correlation. Poor agreement was found for rating items whose assessment required more subjective interpretation.

AGREE II Domain scores can be used to identify strengths and limitations of guidelines and provide an indication of their methodological quality. Median domain scores were highest for domain I, concerned with the overall aim of the guideline, the specific health questions tackled, and the target population, and domain IV, relating to the language, structure, and format of the guideline. These features are expected to score highly given the scope of the ASGs selected and the pre-determined inclusion criteria. The low median score for developmental rigor reflects a failure to detail methodological steps undertaken to evaluate the available evidence and to formulate recommendations. This information was frequently omitted from the ASGs, prohibiting consideration and prompting low scores. The retrospective application of the AGREE II instrument in this study imposes limitations as the ASGs may not have been designed with the AGREE criteria in mind, and it is possible that the true level of engagement with systematic processes is underestimated. Additionally the absence of adequate resources to exercise a systematic approach and the poor evidence base concerning AMU in small animals may favor a consensus-led approach to formulating recommendations.

Domain $\mathrm{V}$ covers aspects pertaining to guideline implementation and uptake that would routinely be included as Supplementary Materials. Item 20, relating to resource implications, is not applicable; antimicrobial cost information will depend on multiple other factors outside the remit of ASGs. Within the AGREE II analysis, Supplementary Materials can be consulted but was not routinely available to the appraisers in this study. The lowest median domain score related to editorial independence reflecting a failure to declare conflicts of interest or the role of any funding bodies. Nonetheless, these ASG have been developed by veterinarians, often contributing their time and expertise voluntarily. The low score recorded here is a reminder of the value of transparency; future guideline developers should include appropriate declarations.

Heterogeneity (exemplified by the wide range for some domain scores) was particularly high for domain II. In human medicine, stakeholder, especially patient, engagement is considered a necessary component of guideline development and implementation [76]. By making recommendations and setting outcomes that are relevant and important to key stakeholders, rapid meaningful change in antimicrobial prescribing behavior can be achieved [77]. In the context of these ASGs, stakeholders include the pet owner and the primary care veterinarians. Ensuring active involvement of different stakeholder groups has underpinned the successful Prescribing Champion Programme for Welsh veterinary 
farm practices [78]. Straightforward and cost-effective means to survey the views of stakeholder groups for veterinary guidelines will afford them a valuable influence. However, escalating methodological standards must be balanced to expected incremental benefits and should not present obstacles to guideline production [79].

At present, there are no empirical data to link AGREE II domain scores with guideline implementation outcomes. The ultimate success of any ASG is judged on its impact on total and specific antimicrobial usage and the degree of prescriber adherence. Frustratingly studies have shown a high frequency of antimicrobial prescription for conditions where AMU is routinely discouraged (e.g., acute diarrhea, acute vomiting, and acute upper respiratory tract disease) demonstrating that inappropriate antimicrobial prescription remains a significant issue [59]. ASG form part of an enablement approach to stewardship [14]. It is hoped that through sustained prescriber engagement, AMU can be optimized (e.g., shifting away from using critically important antimicrobials) and, ultimately reduced. However, the transfer of knowledge alone may be insufficient to influence prescriber behavior [80] and additional measures that address emotional, cognitive and interpersonal factors are warranted to effectuate meaningful change [81,82].

In people, the ability of ASGs to cause a decrease in AMU without adversely affecting patient outcome has been established in low- and middle-income countries as well as in hospital inpatient and outpatient settings in the USA [83-85]. Few studies have described the adherence to guidelines and/or the effect of guidelines on antimicrobial prescription habits among small-animal veterinarians. Awareness of small-animal guidance among prescribers in the UK has been demonstrated [86]. This may not automatically mean that the guidance is followed as adherence to recommendations was poor in both university hospitals and private veterinary practices in Switzerland [87]. More encouragingly, efficacy of hospital policy and national ASGs to positively influence prescription habits of smallanimal practitioners has been shown in Canada and Denmark [55,88-91].

Improved access to AMU data and auditing systems are needed to comprehensively evaluate the impact of ASGs. Currently, quantification of AMU in small animals on an international scale, is based on tablet sales in individual nations [5,92] providing only an approximate indication of total usage in each species and no indication of the appropriateness of AMU or the degree of adherence to guidelines. The network on quantification of veterinary antimicrobial usage at herd level and analysis, communication and benchmarking to improve responsible usage (AACTING) has developed a centralized European resource that lists existing systems [93]. Monitoring systems have evolved in recent years and offer the potential to fill this information gap.

\section{Practical Impact of Our Findings and Recommendations}

This study provides an overview of the available AMU guidelines in small-animal veterinary practice and sheds light on the need for national guidance documents in multiple European countries. National bodies are encouraged to prioritize guideline development in small animals. This study provides a framework highlighting some of the fundamental stewardship principles that should be integral to future ASG and encourages guideline developers to adopt systematic and transparent methodologies. Academia, funding agencies and governmental institutions should prioritize future research to address deficiencies in the AMU evidence base. Guidelines must be sufficiently flexible and dynamic to be of value to the local population of users; engagement of relevant stakeholders can help address the specific needs of the target audience. Means to readily collate data relating to AMU in dogs and cats are required to enable auditing of the impact of ASGs. Demonstration of the long-term efficacy and cost-effectiveness of these interventions to combat AMR would validate the efforts of ASG developers and stimulate the further optimization of this field.

Supplementary Materials: The following are available online at https:/ / www.mdpi.com/article/10 .3390/antibiotics10040409/s1, Table S1: Excluded antimicrobial stewardship guidelines, Supplementary files S2 and S3. 
Author Contributions: The study protocol was conceived and designed by F.A., L.P.C., J.D., P.D., D.T., C.J.P., A.M. and L.R.J., J.G.-R., P.D. and F.A. disseminated requests for information to members of the ENOVAT Cost Action. Descriptive data analysis was performed by F.A., C.P. and A.F.B. AGREE II training and appraisals were performed by F.A., A.F.B., E.B., B.C., M.-E.F., E.H., M.N., C.P. and F.Z. All authors have read and agreed to the published version of the manuscript.

Funding: This research received no external funding.

Institutional Review Board Statement: An application for ethical approval was reviewed by the Ethical Review Board of the University of Liverpool but as no animals or patients were used in the study and no personal information was collected, this study was deemed to not require ethical approval.

Data Availability Statement: The datasets used and/or analyzed during the current study are made available as Supplementary files (S2 and S3).

Acknowledgments: This article is based upon work from the COST Action European Network for Optimization of Veterinary Antimicrobial Treatment (CA18217), supported by European Cooperation in Science and Technology (COST); see: www.enovat.eu and www.cost.eu, assessed date: 15 January 2021. The authors are especially grateful to ENOVAT country representatives and other contacts for completing the search for antimicrobial stewardship guidelines in their countries. Thanks to: Mentor Alishani, Ilias Apostolakos, Naim Deniz Ayaz, Luca Bano, Aivars Bērziňš, Ferenc Biro, Lucia Birosova, Tereza Bodnorova, Myriam Borman, Petra Cagnardi, Giorgi Chakhunashvili, Sonila Cocoli, Elsa Leclerc Duarte, Clair Firth, Paola Grenni, Luca Guardabassi, Josipa Habus, Piret Kalmus, Eran Levy, Peter Kopp, Aneliya Milanova, Slavcho Mrenoshki, Aleksandr Novoslavskij, Charlotta Oddsdottir, Alessandra Piccirillo, Constanca Pomba, Nikola Puvača, Magdalena Rzewuska, Simone Schuller, Ahmed Smajlović, Dragica Stojanović, Pohjanvirta Tarja, Ana Vale, Romel Velev, Ulrika Windahl and Irena Zdovc.

Conflicts of Interest: The authors declare that they have no conflicts of interest.

\section{References}

1. Cassini, A.; Diaz Högberg, L.; Plachouras, D.; Quattrocchi, A.; Hoxha, A.; Simonsen, G.S.; Colomb-Cotinat, M.; Kretzschmar, M.E.; Devleesschauwer, B.; Cecchini, M.; et al. Attributable deaths and disability-adjusted life-years caused by infections with antibiotic-resistant bacteria in the EU and the European Economic Area in 2015: A population-level modelling analysis. Lancet Infect. Dis. 2019, 19, 56-66. [CrossRef]

2. O'Neill, J. Tackling Drug-Resistant Infections Globally: Final Report and Recommendations. In The Review on Antimicrobial Resistance; HM Government: London, UK, 2016.

3. Klein, E.Y.; Van Boeckel, T.P.; Martinez, E.M.; Pant, S.; Gandra, S.; Levin, S.A.; Goosens, H.; Laxaminarayan, R. Global increase and geographic convergence in antibiotic consumption between 2000 and 2015. Proc. Natl. Acad. Sci. USA 2018, 115, E3463-E3470. [CrossRef] [PubMed]

4. Woolhouse, M.; Ward, M.; van Bunnik, B.; Farrar, J. Antimicrobial resistance in humans, livestock and the wider environment. Philos. Trans. R. Soc. Lond. Ser. B Biol. Sci. 2015, 370, 20140083. [CrossRef]

5. European Medicines Agency; European Surveillance of Veterinary Antimicrobial Consumption. Sales of Veterinary Antimicrobial Agents in 31 European Countries in 2018; EMA/24309/2020; European Medicines Agency: Amsterdam, The Netherlands, 2020.

6. Borck Høg, B.; Bager, F.; Korsgaard, H.B.; Ellis-Iversen, J.; Pedersen, K.; Jensen, L.B.; Hendriksen, R.S.; Bortolaia, V.; Rhod Larsen, A.; Petersen, A.; et al. DANMAP 2017-Use of Antimicrobial Agents and Occurrence of Antimicrobial Resistance in Bacteria from Food Animals, Food and Humans in Denmark; Statens Serum Institut, National Veterinary Institute, Technical University of Denmark: Copenhagen, Denmark; National Food Institute, Technical University of Denmark: Copenhagen, Denmark, 2018; Available online: https:/ / backend.orbit.dtu.dk/ws/files/161713656/Rapport_DANMAP_2017.pdf (accessed on 30 March 2021).

7. Ma, G.C.; Worthing, K.A.; Gottlieb, T.; Ward, M.P.; Norris, J.M. Molecular characterization of community-associated methicillinresistant Staphylococcus aureus from pet dogs. Zoonoses Public Health 2019, 67, 222-230. [CrossRef]

8. Morris, D.O.; Loeffler, A.; Davis, M.F.; Guardabassi, L.; Weese, J.S. Recommendations for approaches to meticillin-resistant staphylococcal infections of small animals: Diagnosis, therapeutic considerations and preventative measures: Clinical Consensus Guidelines of the World Association for Veterinary Dermatology. Vet. Dermatol. 2017, 28, 304-e69. [CrossRef]

9. Iseppi, R.; Di Cerbo, A.; Messi, P.; Sabia, C. Antibiotic Resistance and Virulence Traits in Vancomycin-Resistant Enterococci (VRE) and Extended-Spectrum $\beta$-Lactamase/AmpC-producing (ESBL/AmpC) Enterobacteriaceae from Humans and Pets. Antibiotics 2020, 9, 152. [CrossRef] [PubMed]

10. Wada, Y.; Irekeola, A.A.; EA, R.E.N.S.; Yusof, W.; Lih Huey, L.; Ladan Muhammad, S.; Harun, A.; Yean, C.Y.; Zaidah, A.R. Prevalence of Vancomycin-Resistant Enterococcus (VRE) in Companion Animals: The First Meta-Analysis and Systematic Review. Antibiotics 2021, 10, 138. [CrossRef] 
11. Salgado-Caxito, M.; Benavides, J.A.; Adell, A.D.; Paes, A.C.; Moreno-Switt, A.I. Global prevalence and molecular characterization of extended-spectrum $\beta$-lactamase producing-Escherichia coli in dogs and cats-A scoping review and meta-analysis. One Health 2021, 12, 100236. [CrossRef]

12. Pomba, C.; Endimiani, A.; Rossano, A.; Saial, D.; Couto, N.; Perreten, V. First report of OXA-23-mediated carbapenem resistance in sequence type 2 multidrug-resistant Acinetobacter baumannii associated with urinary tract infection in a cat. Antimicrob. Agents Chemother. 2014, 58, 1267-1268. [CrossRef]

13. Reynolds, M.E.; Phan, H.T.T.; George, S.; Hubbard, A.T.M.; Stoesser, N.; Maciuca, I.E.; Crook, D.W.; Timofte, D. Occurrence and characterization of Escherichia coli ST410 co-harbouring blaNDM-5, blaCMY-42 and blaTEM-190 in a dog from the UK. J. Antimicrob. Chemother. 2019, 74, 1207-1211. [CrossRef] [PubMed]

14. Davey, P.; Marwick, C.A.; Scott, C.L.; Charani, E.; McNeil, K.; Brown, E.; Gould, I.M.; Ramsay, C.R.; Michie, S. Interventions to improve antibiotic prescribing practices for hospital inpatients. Cochrane Database Syst. Rev. 2017, 2, CD003543. [CrossRef]

15. Dellit, T.H.; Owens, R.C.; McGowan, J.E., Jr.; Gerding, D.N.; Weinstein, R.A.; Burke, J.P.; Huskins, W.C.; Paterson, D.L.; Fishman, N.O.; Carpenter, P.J.; et al. Infectious Diseases Society of America and the Society for Healthcare Epidemiology of America guidelines for developing an institutional program to enhance antimicrobial stewardship. Clin. Infect. Dis. 2007, 44, 159-177. [CrossRef] [PubMed]

16. Guardabassi, L.; Prescott, J.F. Antimicrobial Stewardship in Small Animal Veterinary Practice. Vet. Clin. N. Am. Small Anim. Pract. 2015, 45, 361-376. [CrossRef] [PubMed]

17. Allerton, F.; Jeffery, N. Prescription rebellion: Reduction of antibiotic use by small animal veterinarians. J. Small Anim. Pract. 2020, 61, 148-155. [CrossRef] [PubMed]

18. Mevius, D.; Heederik, D.J. Reduction of antibiotic use in animals “let's go Dutch". J. Für Verbrauch. Und Lebensm. 2014, 9, 177-181. [CrossRef]

19. Björkman, I.; Röing, M.; Sternberg Lewerin, S.; Stålsby Lundborg, C.; Eriksen, J. Animal Production with Restrictive Use of Antibiotics to Contain Antimicrobial Resistance in Sweden-A Qualitative Study. Front. Vet. Sci. 2021, 7, 619030. [CrossRef]

20. More, S.J. European perspectives on efforts to reduce antimicrobial usage in food animal production. Ir. Vet. J. 2020, 73, 2. [CrossRef]

21. Lloyd, D.H.; Page, S.W. Antimicrobial Stewardship in Veterinary Medicine. In Antimicrobial Resistance in Bacteria from Livestock and Companion Animals; Schwarz, S., Cavaco, L.M., Shen, J., Eds.; Wiley: Hoboken, NJ, USA, 2018.

22. European Parliament, Council of the European Union. Regulation (EU) 2019/6 of the European Parliament and of the Council of 11 December 2018 on veterinary medicinal products and repealing Directive 2001/82/EC (Text with EEA relevance) PE/45/2018/REV/1 OJ L 4, 7.1.2019, p43-167. Available online: https://eur-lex.europa.eu/legal-content/EN/TXT/?uri= CELEX\%3A32019R0006\&qid=1616378125595 (accessed on 1 March 2021).

23. Teale, C.J.; Moulin, G. Prudent use guidelines: A review of existing veterinary guidelines. Rev. Sci. Tech. 2012, 31, 343-354. [CrossRef]

24. AGREE Next Steps Consortium. The AGREE II Instrument 2017. Available online: http:/ / www.agreetrust.org (accessed on 24 February 2020).

25. Hardefeldt, L.; Crabb, H.; Bailey, K.; Johnstone, T.; Gilkerson, J.R.; Billman-Jacobe, H.; Browning, G.F. Appraisal of the Australian Veterinary Prescribing Guidelines for antimicrobial prophylaxis for surgery in dogs and cats. Aust. Vet. J. 2019, 97, 316-322. [CrossRef]

26. Global Repository of Available Guidelines for Responsible Use of Antimicrobials in Animal Health. Available online: http: //www.worldvet.org/news.php?item=417 (accessed on 1 March 2021).

27. WHO Handbook for Guideline Development. Available online: https://apps.who.int/iris/bitstream/handle/10665/75146/9789 241548441_eng.pdf (accessed on 24 February 2020).

28. Cicchetti, D.V. Guidelines, criteria, and rules of thumb for evaluating normed and standardized assessment instruments in psychology. Psychol. Assess. 1994, 6, 284-290. [CrossRef]

29. Formularium AMCRA (Antimicrobial Consumption and Resistance in Animals). Available online: https://formularium.amcra.be (accessed on 1 March 2021).

30. Antibiotic Use Guidelines for Companion Animal Practice (2nd Edition). Available online: https://www.ddd.dk/media/2175 /assembled_final.pdf (accessed on 1 March 2021).

31. Mikrobilääkkeiden Käyttösuositukset Eläinten Tärkeimpiin Tulehdus- ja Tartuntatauteihin. Available online: https://www. ruokavirasto.fi/globalassets/viljelijat/elaintenpito/elainten-laakitseminen/hallittu_laakekekaytto/mikrobilaakekaytonperiaatteet/ mikrobilaakkeiden_kayttosuositukset_en.pdf (accessed on 1 March 2021).

32. Guide De Bonnes Pratiques Filière Animaux De Compagnie Fiches De Recommandations Pour Un Bon Usage Des Antibiotiques. Available online: https://www.veterinaire.fr/fileadmin/user_upload/images/CRO/Languedoc-Roussillon/actualites / AB_ afvac-fiches-antibiotiques-nov16.pdf (accessed on 1 March 2021).

33. Linee Guida. Uso Prudente Dell'antibiotico Negli Animali da Compagnia. Available online: https: / / www.alimenti-salute.it/ sites/default/files/Linee\%20Guida\%20PETs\%202018.pdf (accessed on 1 March 2021).

34. ANMVI. Linee Guida sul Corretto uso Degli Antibioticinella Clinica del Cane e del Gatto, 1st ed.; Edizioni Veterinarie; ANMVI: Cremona, Italy, 2018. 
35. Formularium Gezelschapsdieren Hond, kat en Konijn. Available online: https://www.knmvd.nl/app/uploads/sites/4/2018/0 9/Formularium-Hond-en-Kat.pdf (accessed on 1 March 2021).

36. Terapianbefaling: Bruk av Antibakterielle Midler til Hund og Katt. Available online: https://legemiddelverket.no/Documents/ Veterin $\backslash$ T1 \aermedisin/Terapianbefalinger/Terapianbefaling_Antibakterielle\%20midler\%20hund\%20og\%20katt_2014_N.pdf (accessed on 1 March 2021).

37. Guidelines for the Clinical Use of Antibiotics in the Treatment of Dogs and Cats. Available online: https://www.svf.se/media/ ahwpbt52/policy-ab-english-10b.pdf (accessed on 1 March 2021).

38. Therapieleitfaden für Tierärztinnen und Tierärzte-Hunde und Katzen. Available online: https://docplayer.org/128033855Therapieleitfaden-fuer-tieraerztinnen-und-tieraerzte.html (accessed on 1 March 2021).

39. AntibioticScout.ch. Available online: https:/ / www.vetpharm.uzh.ch/abscout/ (accessed on 1 March 2021).

40. Güneş Tıp Kitabevi. Veteriner Hekimlikte Antibiyotikler (Pratik Bilgiler Rehberi), 2nd ed.; Yarsan, E., Ed.; Güneş Tıp Kitabevi: Ankara, Turkey, 2017.

41. PROTECT ME Poster. Available online: https://www.bsavalibrary.com/docserver/fulltext/10.22233/9781910443644/bsava_ samsoc_protectmeposter_011118web.pdf?expires=1615760031\&id=id\&accname=guest\&checksum=5DC3FBEB23A81F11F399 7F55B04CFFCC (accessed on 1 March 2021).

42. Federation of European Companion Animal Veterinary Associations Recommendations for Appropriate Antimicrobial Therapy. Available online: https:/ / www.fecava.org/wp-content/uploads/2020/01/FECAVA-Recommendations-for-AppropriateAntimicrobial-ENGLISH-1.pdf (accessed on 1 March 2021).

43. Guidance for the Rational Use of Antimicrobials (GRAM) Book. CEVA Sante Animale. 2016. Available online: https://www.ava. com.au/siteassets/advocacy/gram-book---guidance-for-the-rational-use-of-antimicrobials.pdf (accessed on 1 March 2021).

44. Hillier, A.; Lloyd, D.H.; Weese, J.S.; Blondeau, J.M.; Boothe, D.; Breitschwerdt, E.; Guardabassi, L.; Papich, M.G.; Rankin, S.; Turnidge, J.D.; et al. Guidelines for the diagnosis and antimicrobial therapy of canine superficial bacterial folliculitis (Antimicrobial Guidelines Working Group of the International Society for Companion Animal Infectious Diseases). Vet. Dermatol. 2014, 25, 163-e43. [CrossRef]

45. Weese, J.; Giguère, S.; Guardabassi, L.; Morley, P.; Papich, M.; Ricciuto, D.; Sykes, J. ACVIM Consensus Statement on Therapeutic Antimicrobial Use in Animals and Antimicrobial Resistance. J. Vet. Intern. Med. 2015, 29, 487-498. [CrossRef]

46. Lappin, M.R.; Blondeau, J.; Boothe, D.; Breitschwerdt, E.B.; Guardabassi, L.; Lloyd, D.H.; Papich, M.G.; Rankin, S.C.; Sykes, J.E.; Turnidge, J.; et al. Antimicrobial use guidelines for treatment of respiratory tract disease in dogs and cats: Antimicrobial Guidelines Working Group of the International Society for Companion Animal Infectious Diseases. J. Vet. Intern. Med. 2017, 31, 279-294. [CrossRef] [PubMed]

47. Weese, J.S.; Blondeau, J.; Boothe, D.; Guardabassi, L.G.; Gumley, N.; Papich, M.; Jessen, L.R.; Lappin, M.; Rankin, S.; Westropp, J.L.; et al. International Society for Companion Animal Infectious Diseases (ISCAID) guidelines for the diagnosis and management of bacterial urinary tract infections in dogs and cats. Vet. J. 2019, 247, 8-25. [CrossRef]

48. Greenhalgh, T.; Gill, P. Pressure to prescribe involves a complex interplay of factors. BMJ 1997, 315, 1482. [CrossRef]

49. Hopman, N.E.M.; Hulscher, M.; Graveland, H.; Speksnijder, D.C.; Wagenaar, J.A.; Broens, E.M. Factors influencing antimicrobial prescribing by Dutch companion animal veterinarians: A qualitative study. Prev. Vet. Med. 2018, 158, 106-113. [CrossRef] [PubMed]

50. Zhuo, A.; Labbate, M.; Norris, J.M.; Gilbert, G.L.; Ward, M.P.; Bajorek, B.V.; Degeling, C.; Rowbotham, S.J.; Dawson, A.; Nguyen, K.A.; et al. Opportunities and challenges to improving antibiotic prescribing practices through a One Health approach: Results of a comparative survey of doctors, dentists and veterinarians in Australia. BMJ Open 2018, 8, e020439. [CrossRef]

51. Timofte, D.; Broens, E.M.; Guardabassi, L.; Pomba, C.; Allerton, F.; Ikonomopoulos, J.; Overesch, G.; Damborg, P.; European Network for Optimisation of Veterinary Antimicrobial Treatment (ENOVAT); ESCMID Study Group for Veterinary Microbiology (ESGVM); et al. Driving laboratory standardisation of bacterial culture and antimicrobial susceptibility testing in veterinary clinical microbiology in Europe and beyond. J. Clin. Microbiol. 2020. [CrossRef]

52. Guardabassi, L.; Apley, M.; Olsen, J.E.; Toutain, P.-L.; Weese, S. Optimization of Antimicrobial Treatment to Minimize Resistance Selection. Microbiol. Spectr. 2018, 6. [CrossRef]

53. Burke, S.; Black, V.; Sánchez-Vizcaíno, F.; Radford, A.; Hibbert, A.; Tasker, S. Use of cefovecin in a UK population of cats attending first opinion practices as recorded in electronic health records. J. Feline Med. Surg. 2017, 19, 687-692. [CrossRef] [PubMed]

54. Escher, M.; Vanni, M.; Intorre, L.; Caprioli, A.; Tognetti, R.; Scavia, G. Use of antimicrobials in companion animal practice: A retrospective study in a veterinary teaching hospital in Italy. J. Antimicrob. Chemother 2011, 66, 920-927. [CrossRef] [PubMed]

55. De Briyne, N.; Atkinson, J.; Pokludová, L.; Borriello, S.P.; Price, S. Factors influencing antibiotic prescribing habits and use of sensitivity testing amongst veterinarians in Europe. Vet. Rec. 2013, 173, 475. [CrossRef] [PubMed]

56. Varadi, L.; Luo, J.L.; Hibbs, D.E.; Perry, J.D.; Anderson, R.J.; Orenga, S.; Groundwater, P.W. Methods for the detection and identification of pathogenic bacteria: Past, present, and future. Chem. Soc. Rev. 2017, 46, 4818-4832. [CrossRef]

57. Buckland, E.L.; O'Neill, D.; Summers, J.; Mateus, A.; Church, D.; Redmond, L.; Brodbelt, D. Characterisation of antimicrobial usage in cats and dogs attending UK primary care companion animal veterinary practices. Vet. Rec. 2016, 179, 489. [CrossRef]

58. Norris, J.M.; Zhuo, A.; Govendir, M.; Rowbotham, S.J.; Labbate, M.; Degeling, C.; Gilbert, G.L.; Dominey-Howes, D.; Ward, M.P. Factors influencing the behaviour and perceptions of Australian veterinarians towards antibiotic use and antimicrobial resistance. PLOS ONE 2019, 14, e0223534. 
59. Singleton, D.A.; Sánchez-Vizcaínoa, F.; Dawon, S.; Jones, P.H.; Noble, P.J.M.; Pinchbeck, G.L.; Williams, N.J.; Radford, A.D. Patterns of anti-microbial agent prescription in a sentinel population of canine and feline veterinary practices in the United Kingdom. Vet. J. 2017, 224, 18-24. [CrossRef]

60. Robinson, N.J.; Dean, R.S.; Cobb, M.; Brennan, M.L. Factors influencing common diagnoses made during first-opinion smallanimal consultations in the United Kingdom. Prev. Vet. Med. 2016, 131, 87-94. [CrossRef]

61. Summers, J.F.; Hendricks, A.; Brodbelt, D.C. Prescribing practices of primary-care veterinary practitioners in dogs diagnosed with bacterial pyoderma. BMC Vet. Res. 2014, 10, 240. [CrossRef]

62. Magalhães-Sant'Ana, M. Resisting the urge to prescribe vancomycin. In Pract. 2017, 39, 294-295. [CrossRef]

63. McCulloch, S. Comments on the dilemma in the June issue: Resisting the urge to prescribe vancomycin. In Pract. 2017, $39,343$. [CrossRef]

64. WHO. Critically Important Antimicrobials for Human Medicine—6th Review; 6th Revision 2019; World Health Organisation: Geneva, Switzerland, 2019.

65. EMA/AMEG. Categorisation of Antibiotics in the European Union. EMA/CVMP/CHMP/682198/2017. 2019. Available online: https:/ / www.ema.europa.eu/en/documents/report/categorisation-antibiotics-european-union-answer-request-europeancommission-updating-scientific_en.pdf (accessed on 24 February 2020).

66. Spellberg, B. The New Antimicrobial Mantra-“Shorter Is Better”. JAMA Intern. Med. 2016, 176, 1254-1255. [CrossRef]

67. Spellberg, B.; Rice, L.B. Duration of Antimicrobial Therapy: Shorter is Better. Ann. Intern. Med. 2019, 171, 210-211. [CrossRef] [PubMed]

68. Weese, J.S.; Blondeau, J.M.; Boothe, D.; Breitschwerdt, E.B.; Guardabassi, L.; Hillier, A.; Lloyd, D.H.; Papich, M.G.; Rankin, S.C.; Turnidge, J.D.; et al. Antimicrobial use guidelines for treatment of urinary tract disease in dogs and cats: Antimicrobial guidelines working group of the international society for companion animal infectious diseases. Vet. Med. Int. 2011, 2011, 263768. [CrossRef] [PubMed]

69. Pouwels, K.B.; Hopkins, S.; Llewelyn, M.J.; Walker, A.S.; McNulty, C.A.M.; Robotham, J.V. Duration of antibiotic treatment for common infections in English primary care: Cross sectional analysis and comparison with guidelines. BMJ 2019, $364,1440$. [CrossRef]

70. Viitanen, S.J.; Lappalainen, A.K.; Christensen, M.B.; Sankari, S.; Rajamäki, M.M. The Utility of Acute-Phase Proteins in the Assessment of Treatment Response in Dogs with Bacterial Pneumonia. J. Vet. Intern. Med. 2017, 31, 124-133. [CrossRef] [PubMed]

71. Sinclair, D.; Isba, R.; Kredo, T.; Zani, B.; Smith, H.; Garner, P. World Health Organization Guideline Development: An Evaluation. PLoS ONE 2013, 8, e63715. [CrossRef]

72. WHO. Guidelines for WHO Guidelines; WHO Press, World Health Organization: Geneva, Switzerland, 2003; Available online: http:/ /whqlibdoc.who.int/hq/2003/EIP_GPE_EQC_2003_1.pdf (accessed on 1 March 2021).

73. Guyatt, G.H.; Oxman, A.D.; Vist, G.E.; Kunz, R.; Falck-Ytter, Y.; Alonso-Coello, P.; Schünemann, H.J. GRADE: An emerging consensus on rating quality of evidence and strength of recommendations. BMJ 2008, 336, 924-926. [CrossRef] [PubMed]

74. Guyatt, G.; Oxman, A.D.; Akl, E.A.; Kunz, R.; Vist, G.; Jan, B.; Norris, S.; Falck-Ytter, Y.; Glasziou, P.; DeBeer, H.; et al. GRADE guidelines: 1. Introduction-GRADE evidence profiles and summary of findings tables. J. Clin. Epidemiol. 2011, 64, 383-394. [CrossRef]

75. Brouwers, M.C.; Kho, M.E.; Browman, G.P.; Burgers, J.S.; Cluzeau, F.; Feder, G.; Fervers, B.; Graham, I.D.; Grimshaw, J.; Hanna, S.E.; et al. AGREE II: Advancing guideline development, reporting and evaluation in health care. Can. Med Assoc. J. 2010, 182, E839-E842. [CrossRef]

76. Petkovic, J.; Riddle, A.; Akl, E.A.; Khabsa, J.; Lytvyn, L.; Atwere, P.; Campbell, P.; Chalkidou, K.; Chang, S.M.; Crowe, S.; et al. Protocol for the development of guidance for stakeholder engagement in health and healthcare guideline development and implementation. Syst. Rev. 2020, 9, 21. [CrossRef]

77. Wathne, J.S.; Kleppe, L.K.S.; Harthug, S.; Blix, H.S.; Nilsen, R.M.; Charani, E.; The Bergen Intervenion Teams; Smith, I. The effect of antibiotic stewardship interventions with stakeholder involvement in hospital settings: A multicentre, cluster randomized controlled intervention study. Antimicrob. Resist. Infect. Control. 2018, 7, 109. [CrossRef]

78. Rees, G.M.; Bard, A.; Reyher, K.K. Designing a National Veterinary Prescribing Champion Programme for Welsh Veterinary Practices: The Arwain Vet Cymru Project. Antibiotics 2021, 10, 253. [CrossRef] [PubMed]

79. Browman, G.P.; Somerfield, M.R.; Lyman, G.H.; Brouwers, M.C. When is good, good enough? Methodological pragmatism for sustainable guideline development. Implement. Sci. 2015, 10, 28. [CrossRef]

80. Landgren, F.T.; Harvey, K.J.; Moulds, R.F.W.; Mashford, M.L.; Guthrie, B.; Hemming, M. Changing antibiotic prescribing by educational marketing. Med. J. Aust. 1988, 149, 595-599. [CrossRef]

81. Donisi, V.; Sibani, M.; Carrara, E.; Del Piccolo, L.; Rimondini, M.; Mazzaferri, F.; Bovo, C.; Tacconelli, E. Emotional, cognitive and social factors of antimicrobial prescribing: Can antimicrobial stewardship intervention be effective without addressing psycho-social factors? J. Antimicrob. Chemother. 2019, 74, 2844-2847. [CrossRef] [PubMed]

82. Hardefeldt, L.Y.; Gilkerson, J.R.; Billman-Jacobe, H.; Stevenson, M.A.; Thursky, K.; Bailey, K.E.; Browning, G.F. Barriers to and enablers of implementing antimicrobial stewardship programs in veterinary practices. J. Vet. Intern. Med. 2018, 32, 1092-1099. [CrossRef] [PubMed] 
83. Lam, T.T.; Dang, D.A.; Tran, H.H.; Van Do, D.; Le, H.; Negin, J.; Jan, S.; Marks, G.B.; Nguyen, T.A.; Fox, G.J.; et al. What are the most effective community-based antimicrobial stewardship interventions in low- and middle-income countries? A narrative review. J. Antimicrob. Chemother. 2021, dkaa556. [CrossRef]

84. Drekonja, D.; Filice, G.A.; Greer, N.; Olson, A.; MacDonald, R.; Rutks, I.; Wilt, T.J. Antimicrobial Stewardship in Outpatient Settings: A Systematic Review. Infect. Control. Hosp. Epidemiol. 2015, 36, 142-152. [CrossRef]

85. Wagner, B.; Filice, G.A.; Drekonja, D.; Greer, N.; MacDonald, R.; Rutks, I.; Butler, M.; Wilt, T.J. Antimicrobial Stewardship Programs in Inpatient Hospital Settings: A Systematic Review. Infect. Control. Hosp. Epidemiol. 2015, 35, 1209-1228. [CrossRef]

86. Lightman, J.; Battersby, I. Preliminary findings of a survey of UK small animal general practitioners to describe antibiotic use. In BSAVA Congress Proceedings 2018; BSAVA: Birmingham, UK, 2018; pp. 417-418.

87. Lutz, B.; Lehner, C.; Schmitt, K.; Willi, B.; Schüpbach, G.; Mevissen, M.; Peter, R.; Müntener, C.; Naegeli, H.; Schuller, S. Antimicrobial prescriptions and adherence to prudent use guidelines for selected canine diseases in Switzerland in 2016. Vet. Rec. Open 2020, 7, e000370. [CrossRef]

88. Weese, J.S. Investigation of antimicrobial use and the impact of antimicrobial use guidelines in a small animal veterinary teaching hospital: 1995-2004. J. Am. Vet. Med. Assoc. 2006, 228, 553-558. [CrossRef]

89. Jessen, L.R.; Sørensen, T.M.; Lilja, Z.L.; Kristensen, M.; Hald, T.; Damborg, P. Cross-sectional survey on the use and impact of the Danish national antibiotic use guidelines for companion animal practice. Acta Vet. Scand. 2017, 59, 81. [CrossRef]

90. Hopman, N.E.M.; Portengen, L.; Hulscher, M.E.J.L.; Heederik, D.J.J.; Verheij, T.J.M.; Wagenaar, J.A.; Prins, j.; Bosje, T.; Schipper, L.; van Geijlswijk, I.M.; et al. Implementation and evaluation of an antimicrobial stewardship programme in companion animal clinics: A stepped-wedge design intervention study. PLoS ONE 2019, 14, e0225124. [CrossRef] [PubMed]

91. Sarrazin, S.; Vandael, F.; Van Cleven, A.; De Graef, E.; De Rooster, H.; Dewulf, J. De impact van advies omtrent het gebruik van antimicrobiële middelen op het voorschrijfgedrag in veertien Vlaamse praktijken voor kleine huisdieren. (The impact of antimicrobial use guidelines on prescription habits in fourteen Flemish small animal practices). Vlaams Diergeneeskundig Tijdschrift $2017,86,173$.

92. UK-VARSS. Veterinary Antibiotic Resistance and Sales Surveillance Report (UK-VARSS 2019); Veterinary Medicines Directorate: New Haw, UK, 2020.

93. Overview of Farm-Level AMU Monitoring Systems. Available online: https://aacting.org/monitoring-systems (accessed on 1 March 2021). 